\title{
History of Medicine is a science
}

\author{
Ana Cecilia Rodríguez-de Romo
}

Department of History and Philosophy of Medicine, Faculty of Medicine, Universidad Nacional Autónoma de México; Laboratory of History of Medicine, Instituto Nacional de Neurología y Neurocirugía, Ciudad de México, Mexico

History of medicine is not the narrative of past glories or an entertainment for cultured people. This is what my teacher Mirko Grmek (1924-2000), great physician and medicine historian, used to say when he wanted to communicate that this discipline is a specialty of medicine itself, which has its methodology and, as such, should not be treated with indifference or lightness. Taking this principle as a guiding axis, Gaceta Médica de México decided to make an innovative turn to its "History and Philosophy of Medicine" section, which, until its current format, used to be an amalgam, with varying levels of formality, of medical issues and their relationship with humanities and social sciences. That is, now it pursues subtracting these fields from the anecdotic or narrative context and grant them the same academic weight of the rest of its medical-scientific content. The articles that formerly used comprise that section will be included in the "Original Articles" section but, of course, rights imply obligations, and rules will have to be followed. Let's think about the change and those rules.

Tradition has its weight... and that is a good thing! Humans are traditions and customs, and our National Academy of Medicine has known how to preserve them like no other Mexican institution, but circumstances change, they renew and wish we we would grow old innovating as Gaceta Médica de México. Adapting the "History and Philosophy of Medicine" section to modernity by conferring it its scientific value was a very brave and surely difficult decision, given that almost since the beginnings of the journal there were texts published where $19^{\text {th }}$ century physicians showed interest on the past of their science. Without any methodology, they expressed it freely in the $\mathrm{Na}$ tional Academy of Medicine official publication, as they felt it, as they experienced it. That was a good thing because important facts were preserved. The managers of our official publication, in addition to braveness, have courage and are willing to work, since the task will imply putting together a group of reviewers, and learning historiographic currents, authors and topics; in other words, there is a lot that has to be done to confer consistency and seriousness to the section.

Revolving around the history of medicine, a field where I feel comfortable, let's address the issue of the rules, let's discuss about that which makes it a discipline with an identity of its own and that, consequently, grants it the right to be treated as such. Let's talk a bit about its theoretical-methodological bases.

Conceiving the history of medicine as a simple account of dates, names and places makes it boring, but asking, for example, how our predecessors explained how such a large amount of blood was continuously formed, instead of circulating; why did Camillo Golgi see the nervous tissue as a network and not as an evident combination of anatomically and physiologically independent units; what circumstances would cause for the same disease to have such different conceptions in time and places; what were be the challenges women really had to face to join the world medicine, etc. Trying to answer these questions, apart from being fun, is an intellectual challenge and has a heuristic value.

\section{Correspondence:}

Ana Cecilia Rodríguez-de Romo

Laboratorio de Historia de la Medicina

Instituto Nacional de Neurología y Neurocirugía

A. Insurgentes Sur, 3877

Col. la Fama, Del. Tlalpan

C.P. 14269, México

E-mail: ceciliar@unam.mx
Date of reception: 04-12-2017

Date of acceptance: 05-12-2017

DOI://dx.doi.org/10.24875/GMM.M18000121
Gac Med Mex. 2018;154:100-102

Contents available at PubMed www.gacetamedicademexico.com 
But, careful, I am not saying that in order for our question to be of value it has to be complex or difficult, not at all! A simple question, but well elaborated and methodologically answered, will give rise to a valuable, dignified and good work. A conscious, meticulous and honest review of the development of a surgical technique, or of the origin and study of a drug, is as meritorious as the elucidation of a big medical historic event. Similarly, reconstructing the life of an illustrious personality as a human being rather than as a semigod, that is challenging. I believe that the key to a good start is knowing what we want and making a clear question.

In humanities and social sciences it is not possible for experiments to be made as in research laboratories, or finding in practice the adequate dose of a medication for a particular patient. However, questions based on previous knowledge about a particular issue can be proposed without any problem, because we have read about it with great interest, because we exercise its principles, because we know it and because we have studied it. The question is equal to the hypothesis of scientific experiments, and as I already said that it can be crucial or simple. The only condition to scientifically answering it is placing it in the framework of logical and finely structured reasoning, and using a method that is dependent on "sources". The sources are equal to experiments' materials and, in general terms, they are referred to as being secondary and primary. However, it should be recognized that, frequently, the border between both is diffuse, and I will clarify this later.

But let's take the common definitions to understand each other. Let's begin with the secondary sources, because our investigation must start with them. Generally, these sources are the manuscripts of scholars who already worked on the subject or any other similar. We should recognize that perhaps we are not the first ones to formulate our question, or to put it in other words, it is also possible for someone to have done something similar to that which we are interested in. If this is the case, maybe this scholar captured his results in published materials such as books, articles, reviews, commentaries, notes, etc. These works, which are ageless and can be very old or very recent, have to be reviewed; in either case, knowing them is highly useful. In our days, electronic means enable rapid searches, and many times even reading the works. The result of this initial investigation is multiple, from the fact of the question being original and then we have an unexplored field to work, to the fact that the topic has awakened others' curiosity and there are existing published precedents. In the latter case, there is no place for discouragement, since a range of possibilities is also opened to address the subject; for example, not sharing that author's opinion and proposing another approach or, in the light new knowledge, reinterpreting the same issue. But careful, with no exception, do not trust in manuscripts without bibliographic references, in those lacking sources, especially primary sources, or in purely personal opinions or speculations.

Primary sources are generally documents produced in the epoch we are interested in and that very often are unknown. Letters, communications, diaries, minutes, contracts, files, protocols, personal notes, testaments, photographs, censuses, written testimonies, obituaries, announcements... so many materials that are in repositories and even in family drawers! I call these materials the "incorrigible scandalmongers", which at the slightest provocation tell the truth But in addition, they are jealous and egomaniac, because they have to be addressed considering the context of their times, that is, the political, economic, social, historic, cultural and even geographic conditions of the moment they were originated. Let's take an example: the National Medical Institute (Instituto Médico Nacional, IMN, 1888-1925) was a great institution of $19^{\text {th }}$ century Mexico that carried out research adhering to scientific thought and with the purest nationalist feeling. The IMN is so rich, that many national and foreign scholars have been interested and continue to be interested in it, but its work would be faulty without the use of primary sources, such as the endless supply of materials existing in the National Archives. Its consultation shouts for everyone to know that scientific research in Mexico does not date from the $20^{\text {th }}$ century, that those who went down in history as the bad guys were not such thing, that unknown personalities should be known and that Mexican science cannot be judged with the parameters of developed countries, since it had its own objectives and needs.

Dealing with primary sources can be highly gratifying or highly frustrating. Gratifying, because in the best case scenario we can make "discoveries" and frustrating because most of the times, the archives are warehouses of disordered papers in dark, cold and isolated places, where one virtually has to launch into the unknown in search for something we don't know for sure what it is. Often, the result is not consistent with the effort. However, in either two cases, they have to be worked on, it is good for them exist and 
not to be destroyed, as the tendency appears to be in more recent years.

There are materials that are difficult to classify, since according to their use they could be primary or secondary sources, and even both. Newspapers and movies would represent this case. They were produced by somebody, who certified or testified about something at the time; maybe they have been hidden in time, and according to how they are approached, they can be a primary or secondary source.

After making a question and trying to methodologically answering it, comes the real defiance, the intellectual challenge: the interpretation, explanation, the construction of something that doesn't exist anymore, the writing. It has to be written conveying a message, resuming our hypothesis and providing knowledge. In this step, one has to think on how the existing knowledge was acquired, on how the existing beliefs were justified; one has to try to put oneself in the other's shoes, go back to the initial question and observe in the light of what we found, but without judging that past with the eyes of the present. Essentially, the historical method does not differ from the experimental method: how would they justify the belief on miasmas; what would have the creators of Mexican public health really thought and seen to do what they did; what would have been female pioneers of medicine true motivation to choose a traditionally masculine career; what would have Watson and Crick imagined when, in their seminal article, they suggested that their observation would answer yet unknown questions. Many times, the initial question is transformed after the research and becomes more attractive or interesting. We all can propose questions; the only condition to answer them is not doing it with indolence, with prejudice or as dilettantes.

Historians (read: sociologists, philosophers, anthropologists) complain that doctors only narrate things, they do not analyze them, they don't know the method, do not consider the context, misinterpret the past, do not consult the sources, minimize errors and exaggerate successes. Doctors claim that historians (read as suggested above) are unaware of medical knowledge and make history of medicine without medicine, that they ignore the reality of dealing with disease and suffering, and are theoretical, boring and detail-oriented. This useless controversy has not led to anything, and I am convinced that Gaceta Médica de México is an ideal platform for medical humanities and sociomedicine to be seriously expressed. The National Academy of Medicine and its journal have always displayed generosity and have adopted the multidisciplinary or interdisciplinary focus.

In our country we have no specific publication to diffuse the work of scholars in these areas, and we have to turn our eyes to other countries if we want to publish the results of our investigation. Some years ago we endeavored in the creation of a good journal of history of medicine, but we ultimately did not succeed with maintaining and consolidating it. The support of the Mexican Academy of Medicine, which in addition holds a chair in the area, will be fundamental to meet that purpose.

I am aware that many things were left out of this disquisition advocating for history of medicine (read: humanities and social sciences interested in medicine), my particular space of academic development, but the purpose was to argue in favor of an innovative project of the Gaceta Médica de México editors. In addition, our journal has always have its doors open to anthropology, ethics, philosophy, social sciences, economic sciences and even political sciences involved with medicine. Let's take this opportunity with seriousness, let's support it and work to its benefit. 